ARTICLE

https://doi.org/10.1038/s41467-021-26916-2

\title{
An abiotic source of Archean hydrogen peroxide and oxygen that pre-dates oxygenic photosynthesis
}

\author{
Hongping He (1) 1,2,3,6凶 , Xiao Wu (1) 1,2,3,6, Haiyang Xian (1) 1,2, Jianxi Zhu (1) 1,2,3, Yiping Yang 1,2,3, Ying Lv (1) 1,2,3, \\ Yiliang Li (i) ${ }^{4 凶} \&$ Kurt O. Konhauser ${ }^{5 凶}$
}

The evolution of oxygenic photosynthesis is a pivotal event in Earth's history because the $\mathrm{O}_{2}$ released fundamentally changed the planet's redox state and facilitated the emergence of multicellular life. An intriguing hypothesis proposes that hydrogen peroxide $\left(\mathrm{H}_{2} \mathrm{O}_{2}\right)$ once acted as the electron donor prior to the evolution of oxygenic photosynthesis, but its abundance during the Archean would have been limited. Here, we report a previously unrecognized abiotic pathway for Archean $\mathrm{H}_{2} \mathrm{O}_{2}$ production that involves the abrasion of quartz surfaces and the subsequent generation of surface-bound radicals that can efficiently oxidize $\mathrm{H}_{2} \mathrm{O}$ to $\mathrm{H}_{2} \mathrm{O}_{2}$ and $\mathrm{O}_{2}$. We propose that in turbulent subaqueous environments, such as rivers, estuaries and deltas, this process could have provided a sufficient $\mathrm{H}_{2} \mathrm{O}_{2}$ source that led to the generation of biogenic $\mathrm{O}_{2}$, creating an evolutionary impetus for the origin of oxygenic photosynthesis.

\footnotetext{
${ }^{1}$ CAS Key Laboratory of Mineralogy and Metallogeny/Guangdong Provincial Key Laboratory of Mineral Physics and Materials, Guangzhou Institute of Geochemistry, Chinese Academy of Sciences, 510640 Guangzhou, China. ${ }^{2}$ CAS Center for Excellence in Deep Earth Science, 510640 Guangzhou, China. ${ }^{3}$ University of Chinese Academy of Sciences, 100049 Beijing, China. ${ }^{4}$ Department of Earth Sciences, The University of Hong Kong, 999077 Hong Kong, China. ${ }^{5}$ Department of Earth and Atmospheric Sciences, University of Alberta, Edmonton, Alberta T6G 2E3, Canada. ${ }^{6}$ These authors contributed equally: Hongping He, Xiao Wu. 凶email: hehp@gig.ac.cn; yiliang@hku.hk; kurtk@ualberta.ca
} 
T he evolution of oxygenic photosynthesis was a critical biological innovation that allowed water to be used as an electron source and dioxygen gas $\left(\mathrm{O}_{2}\right)$ to be released as a metabolic by-product to the early atmosphere. Oxygenic photosynthesis operates by a four-electron reaction (R1) process associated with chlorophyll- $a$ and the water-oxidizing complex $(\text { WOC })^{1,2}$. However, it would have been difficult for the ancestor of modern cyanobacteria to extract four electrons from water, a very stable compound, before the development of chlorophyll- $a$ and the $\mathrm{WOC}^{2-4}$. Thus, it has been proposed that there might have been a transitional electron donor prior to $\mathrm{H}_{2} \mathrm{O}$ for the evolution of oxygenic photosynthesis on the early Earth ${ }^{3}$.

$$
2 \mathrm{H}_{2} \mathrm{O} \rightarrow \mathrm{O}_{2}+4 \mathrm{H}^{+}+4 \mathrm{e}^{-}
$$

Many intermediates have been proposed ${ }^{1,3,5-8}$, but only hydrogen peroxide $\left(\mathrm{H}_{2} \mathrm{O}_{2}\right)$, divalent manganese $\left(\mathrm{Mn}^{2+}\right)$, and bicarbonate $\left(\mathrm{HCO}_{3}{ }^{-}\right)$satisfy the multi-electron chemistry requirements. As an early intermediate candidate prior to $\mathrm{H}_{2} \mathrm{O}$, $\mathrm{H}_{2} \mathrm{O}_{2}$ is plausible for two reasons. First, it can be oxidized at electrochemical potentials that are accessible to existing anoxygenic phototrophs ${ }^{1}$, meaning that if photosynthesis evolved as an anoxygenic process, as is generally accepted ${ }^{9}$, the photosynthetic machinery might already have been in place to handle $\mathrm{H}_{2} \mathrm{O}_{2}$ redox transformations. Second, $\mathrm{H}_{2} \mathrm{O}_{2}$ and the by-product $\left(\mathrm{O}_{2}\right)$ would have consumed the surrounding reductants used by anoxygenic photosynthesizers (e.g., $\mathrm{H}_{2}, \mathrm{H}_{2} \mathrm{~S}, \mathrm{Fe}^{2+}$ ), creating evolutionary pressure that forced existing photoautotrophs to adapt to locally oxidized environments and to utilize new electron donors ${ }^{6}$, assuming a large sustained $\mathrm{H}_{2} \mathrm{O}_{2}$ source. Blankenship and Hartman ${ }^{1}$ further developed a hypothesis that involves $\mathrm{H}_{2} \mathrm{O}_{2}$ as a transitional electron donor in a two-electron reaction releasing oxygen within a primitive system composed of an anoxygenic photosynthetic reaction center and a binuclear $\mathrm{Mn}$ catalase enzyme (R2).

$$
2 \mathrm{H}_{2} \mathrm{O}_{2} \rightarrow 2 \mathrm{H}_{2} \mathrm{O}+\mathrm{O}_{2}
$$

Regardless of the disputes on the structural homology between the binuclear $\mathrm{Mn}$-catalase and four $\mathrm{Mn}$-containing core of the WOC ${ }^{2,10}$, electrons in $\mathrm{H}_{2} \mathrm{O}_{2}$ can also be extracted by the $\mathrm{Mn}$ cluster that might directly evolve from inorganic $\mathrm{Mn}$ complexes $^{11}$, such as manganese bicarbonate ${ }^{12}$ and a variety of $\mathrm{MnO}_{2}$ minerals ${ }^{13}$. Thus, $\mathrm{H}_{2} \mathrm{O}_{2}$ could have played a key role in the developmental stage of oxygenic photosynthesis, but for that process to endure, it would have depended on the continuous availability of an exogenous source of $\mathrm{H}_{2} \mathrm{O}_{2}$.

Several abiotic geochemical sources of $\mathrm{H}_{2} \mathrm{O}_{2}$ were proposed to have existed on the early Earth ${ }^{14-18}$. For instance, Kasting ${ }^{14,19}$ proposed a photochemical model in which $\mathrm{H}_{2} \mathrm{O}_{2}$ was produced from the photolysis of $\mathrm{H}_{2} \mathrm{O}$ in the early stratosphere and reached the ground via precipitation. The flux of $\mathrm{H}_{2} \mathrm{O}_{2}$ on the surface of the early Earth was calculated to be $\sim 10^{6}$ molecules $\mathrm{cm}^{-2} \mathrm{~s}^{-1}$ based on a 0.2 -bar $\mathrm{CO}_{2}$ photochemical model ${ }^{20}$, resulting in a dissolved $\mathrm{O}_{2}$ concentration maximum of $0.08 \mathrm{nM}$ in the surface water when all $\mathrm{H}_{2} \mathrm{O}_{2}$ decomposed to $\mathrm{O}_{2}$ and $\mathrm{H}_{2} \mathrm{O}$. Pecoits et al. ${ }^{21}$ similarly calculated a rate of $\sim 10^{6}$ molecules $\mathrm{cm}^{-2} \mathrm{~s}^{-1}$ assuming lower $\mathrm{pCO}_{2}$ of $0.01-0.1$ bar. These theoretical calculations ${ }^{14,19-21}$ collectively suggest that the ground level of photochemically produced $\mathrm{H}_{2} \mathrm{O}_{2}$ is very low because of the low atmospheric $\mathrm{H}_{2} \mathrm{O}$ vapor and the short atmospheric lifetime of $\mathrm{H}_{2} \mathrm{O}_{2}$ against ultraviolet photolysis in the stratosphere. Importantly, the trace levels of $\mathrm{H}_{2} \mathrm{O}_{2}$ by photochemical process alone would be insufficient to fuel the respiration of the smallest cells $\left(3 \mathrm{nM}\right.$ dissolved $\left.\mathrm{O}_{2}\right)$, yet high enough for developing a defense against oxygen toxicity ${ }^{20,22}$. Although it has been proposed that substantial photochemically produced $\mathrm{H}_{2} \mathrm{O}_{2}$ stored in glaciers might have been released to the oceans following a Snowball Earth event ${ }^{23}$, the occurrence of possibly the earliest extensive glaciation (the Pongola glaciations at $\sim 2.9 \mathrm{Gyr})^{24}$ is still much later than the development time of oxygen-utilizing enzymes $(\sim 3.1 \mathrm{Gyr})^{25}$.

Here we report experimental evidence for an overlooked mechanism for producing a stable abiotic source of reactive oxygen species (ROS, including $\mathrm{H}_{2} \mathrm{O}_{2}$ and $\bullet \mathrm{OH}$ ) involving water reacting with newly abraded surfaces of quartz $\left(\mathrm{SiO}_{2}\right)$. Specifically, $\mathrm{O}_{2}$ and ROS are produced by reactions between water and the surface-bound radicals (SBRs), such as $\equiv \mathrm{SiO} \bullet$ and $\equiv \mathrm{SiOO}$, under strictly anoxic conditions. These SBRs are highly reactive surface defects on quartz and various other types of silicate minerals (e.g., pyroxene) 26,27 $^{6}$ that can be created by the mechanical homolysis of $\mathrm{Si}-\mathrm{O}$ bonds ${ }^{28}$ through hydrological processes that induce quartz abrasion (e.g., currents, waves, and tides). We hypothesize that the persistent generation of $\mathrm{H}_{2} \mathrm{O}_{2}$ at quartz-water interfaces in rivers, estuaries, and deltas could have provided a source of $\mathrm{H}_{2} \mathrm{O}_{2}$ that stimulated the emergence of oxygenic photosynthesis from anaerobic predecessors on the early Earth $^{1,6}$.

\section{Results and discussion}

The SBR-induced generation of ROS at the abraded quartzwater interface. We selected quartz for examination because it is the most abundant weathering end-product mineral in terrestrial environments and there is $>3.2 \mathrm{Ga}$ record of extensive quartz sandstones in high-energy aqueous environments ${ }^{29}$. Its basic unit, the $\left[\mathrm{SiO}_{4}\right]^{4-}$ tetrahedron, is the structural unit of all silicate minerals. $\mathrm{Si}-\mathrm{O}$ bonds in $\left[\mathrm{SiO}_{4}\right]^{4-}$ tetrahedrons are mixtures of both ionic and covalent bonds ${ }^{30}$, thus the rupture of $\mathrm{Si}-\mathrm{O}$ bonds can produce SBRs with unpaired electrons (such as $\equiv \mathrm{SiO}$. and $\equiv \mathrm{SiOO} \cdot)^{31}$ which can split water molecules and produce ROS. Previous studies investigated the formation of radicals on the surface of pulverized minerals and their role in pathogenicity ${ }^{32-37}$, which suggest that SBRs and the ROS produced are sensitive to the presence of atmospheric $\mathrm{O}_{2}$ and $\mathrm{H}_{2} \mathrm{O}$. To avoid the false positive results induced by pre-existing $\mathrm{O}_{2}$, we performed ball-milling of quartz sands $(0.25-0.6 \mathrm{~mm})$ in an $\mathrm{O}_{2}$ free, $\mathrm{N}_{2}$ atmosphere $\left(\mathrm{O}_{2}<0.1 \mathrm{ppm}\right)$ and obtained a fine powder of quartz with a median particle size of $0.002 \mathrm{~mm}$ (Supplementary Fig. 1).

We investigated the feasibility of the formation of SBRs on the surface of the abraded quartz on Earth before its atmosphere accumulated free oxygen, e.g., the Great Oxidation Event (GOE), which occurred at $\sim 2.45$ to $2.3 \mathrm{Gyr}$ ago ${ }^{38,39}$. We observed that the abrasion of quartz led to simultaneous formation of charged surface sites through heterolysis (i.e., $\equiv \mathrm{Si}_{-}-\mathrm{O}^{-}$and $\equiv \mathrm{Si}^{+}$, as per R3) and SBRs with unpaired electrons through homolysis (i.e., $\equiv \mathrm{Si}-\mathrm{O} \bullet$, and $\equiv \mathrm{Si} \bullet$, and $\equiv \mathrm{Si}-\mathrm{O}-\mathrm{O} \bullet$, as per $\left.\mathrm{R}^{-}-5\right)^{28,40}$ on the quartz surfaces (Fig. 1a). In turn, this led to the generation of $\mathrm{E}^{\prime}$ center $(\equiv \mathrm{Si} \bullet)$, peroxy radical $(\equiv \mathrm{SiOO} \bullet)$, and superoxide ion $\left(\equiv \mathrm{Si}^{+} \mathrm{O}_{2}{ }^{\cdot-}\right)$ species. By contrast, there is no SBR on the aged surface of intact quartz. The SBRs were derived from the homolysis of $\equiv \mathrm{Si}-\mathrm{O}-\mathrm{Si} \equiv$ (intrinsic bonds in quartz) and $\equiv \mathrm{Si}-\mathrm{O}-\mathrm{O}-\mathrm{Si} \equiv(\mathrm{a}$ peroxy linkage formed during mechanical deformations ${ }^{41}$ ).

$$
\begin{gathered}
\equiv \mathrm{Si}-\mathrm{O}-\mathrm{Si} \equiv \rightarrow \equiv \mathrm{Si}-\mathrm{O}^{-}+\equiv \mathrm{Si}^{+} \\
\equiv \mathrm{Si}-\mathrm{O}-\mathrm{Si} \equiv \rightarrow \equiv \mathrm{Si}-\mathrm{O} \bullet+\equiv \mathrm{Si} \bullet \\
\equiv \mathrm{Si}-\mathrm{O}-\mathrm{O}-\mathrm{Si} \equiv \rightarrow \equiv \mathrm{Si}-\mathrm{O}-\mathrm{O} \bullet+\equiv \mathrm{Si} \bullet
\end{gathered}
$$

X-ray diffraction (XRD) analyses were performed to further examine whether the generation of SBRs were related to structural changes during quartz abrasion. The XRD patterns show that the abraded quartz has distinctive variations in its quintuple lines that are consistent with the presence of crystal 


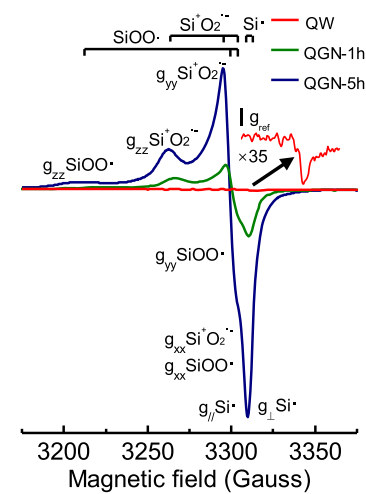

b

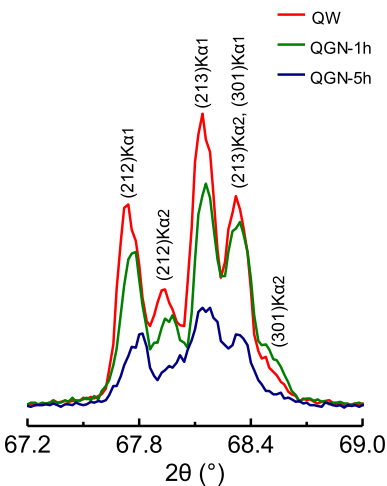

Fig. 1 Mechanically induced surface-bound radicals and structural amorphization of quartz. a EPR spectra of quartz before and after being ground in $\mathrm{N}_{2}$ for 1 and $5 \mathrm{~h}$. Three types of surface-bound radicals were identified, i.e., peroxy radical ( $\equiv$ SiOO $\bullet, g_{\mathrm{zz}}=2.064 ; g_{\mathrm{yy}}=2.007$; $\left.g_{\mathrm{xx}}=2.002\right)$, surface-bound superoxide ion $\left(\equiv \mathrm{Si}^{+} \mathrm{O}_{2}{ }^{\bullet-}, g_{\mathrm{zz}}=2.044\right.$; $g_{\mathrm{yy}}=2.010 ; g_{\mathrm{xx}}=2.002$ ), and $\mathrm{E}^{\prime}$ center ( $\equiv$ Si $\bullet, g_{/ /}=2.001 ; g_{\perp}=2.000$ ). b XRD patterns of quartz washed by $10 \mathrm{wt} \%$ hydrofluoric acid (QW) and quartz ground in $\mathrm{N}_{2}$ atmosphere for $1 \mathrm{~h}$ (QGN-1h) and $5 \mathrm{~h}$ (QGN-5h).

defects (Fig. 1b), i.e., the five characteristic diffraction peaks of quartz crystals changed from sharp-and-narrow to weak-andbroad of those with the abrasion caused basal slip ${ }^{41}$. Correspondingly, transmission electron microscopy (TEM) observations demonstrated that the amorphous layer that formed on the surface of the abraded quartz increased with a longer time of ballmilling (Supplementary Fig. 2). More importantly, electron paramagnetic resonance (EPR) measurements (Fig. 1a) showed that the increase in $\mathrm{E}^{\prime}$ center $(\equiv \mathrm{Si} \bullet)$ and oxygen radicals $(\equiv \mathrm{SiO} \bullet$ and $\equiv \mathrm{SiOO} \bullet$ ) was related to the increment in the thickness of the mechanically induced amorphous layer on the surface of the crystalline quartz.

We then examined the interaction between the resultant SBRs and water by submerging the abraded quartz into the oxygen-free water in a glovebox under an ultra-pure nitrogen atmosphere. We observed that the reaction led to the generation not only of ROS, such as hydroxyl radicals $(\bullet \mathrm{OH})$ and $\mathrm{H}_{2} \mathrm{O}_{2}$ (Fig. 2a), but also of dissolved oxygen (Fig. 2b). The accumulation of these oxidants was demonstrated by a concomitant increase in the redox potential (from $\sim 0$ to $150 \mathrm{mV}$ ) at a near-constant $\mathrm{pH}(\mathrm{pH} \approx 3.77$; Fig. 2b).

Measurements of the kinetics of ROS and $\mathrm{O}_{2}$ release under anoxic conditions at the abraded quartz-water interfaces showed three stages. During the first stage $(0-5 \mathrm{~min})$, the reaction between SBRs and $\mathrm{H}_{2} \mathrm{O}$ led to a rapid increase in the concentrations of $\cdot \mathrm{OH}, \mathrm{H}_{2} \mathrm{O}_{2}$, and dissolved $\mathrm{O}_{2}$ in the suspension, resulting from reactions R6-R10.

$$
\begin{gathered}
\equiv \mathrm{SiO} \bullet+\mathrm{H}_{2} \mathrm{O} \rightarrow \equiv \mathrm{SiOH}+\bullet \mathrm{OH} \\
2 \cdot \mathrm{OH} \rightarrow \mathrm{H}_{2} \mathrm{O}_{2} \\
\equiv \mathrm{SiOO} \bullet+\mathrm{H}_{2} \mathrm{O} \rightarrow \equiv \mathrm{SiOH}+\mathrm{HO}_{2} \bullet \\
\equiv \mathrm{Si}^{+} \mathrm{O}_{2}^{--}+\mathrm{H}_{2} \mathrm{O} \rightarrow \equiv \mathrm{SiOH}+\mathrm{HO}_{2} \bullet \\
\quad \mathrm{HO}_{2} \bullet \rightarrow 0.5 \mathrm{H}_{2} \mathrm{O}_{2}+0.5 \mathrm{O}_{2}
\end{gathered}
$$

During the second stage $(5-120 \mathrm{~min})$, fluctuations in the concentrations of ROS and dissolved $\mathrm{O}_{2}$ were observed (Fig. 2b). The first slowdown in the increase of cumulative $\cdot \mathrm{OH}$ concentration was attributed to a decrease in the exposure rate of SBRs, resulting in the suppression of R6. In turn, the decreased
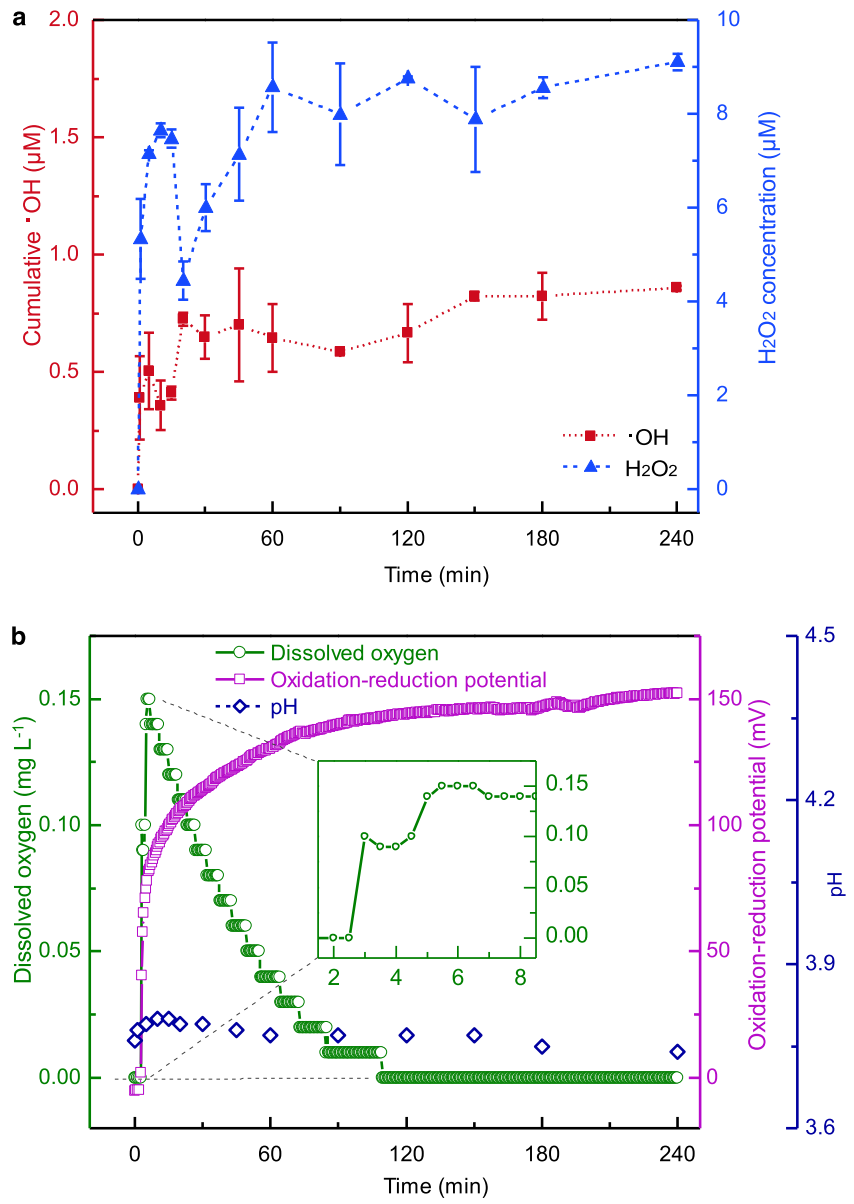

Fig. 2 Time-course of $\bullet \mathrm{OH}, \mathrm{H}_{2} \mathrm{O}_{2}$, and $\mathrm{O}_{2}$ concentrations in quartz-water interface reactions. a The cumulative $\bullet \mathrm{OH}$ (filled square) and the concentration of $\mathrm{H}_{2} \mathrm{O}_{2}$ (filled triangle) in the suspension of quartz ground in $\mathrm{N}_{2}$ atmosphere for $5 \mathrm{~h}$. The error bars present standard deviations of two independent replicates. $\mathbf{b}$ The variations of dissolved oxygen concentrations (open circle), oxidation-reduction potential (open square), and $\mathrm{pH}$ (open diamond) in the reactions. All the independent experiments were conducted in duplicate using water with dissolved oxygen $<0.01 \mathrm{mg} \mathrm{L}^{-1}$ in a glovebox with $\mathrm{N}_{2}$.

$[\bullet \mathrm{OH}]$ restricted the generation of $\mathrm{H}_{2} \mathrm{O}_{2}$ (R7). Moreover, both the decrease of SBR exposure (R8-R9) and consumption of $\mathrm{H}_{2} \mathrm{O}_{2}$ by other radicals (e.g., $\equiv \mathrm{Si}^{+} \mathrm{O}_{2}{ }^{-}$) via $\mathrm{R} 11$ - the Haber-Weiss reaction ${ }^{28}$ - resulted in a decreased $\left[\mathrm{H}_{2} \mathrm{O}_{2}\right]$. The subsequent increase in $\left[\mathrm{H}_{2} \mathrm{O}_{2}\right]$ was negatively correlated to the concentration of the dissolved $\mathrm{O}_{2}$. This is due to the dissolved $\mathrm{O}_{2}$ produced in the intermediate reactions ( $\mathrm{R} 10-\mathrm{R} 11)$ reacted with $\mathrm{H} \bullet$ to form $\mathrm{HO}_{2} \bullet(\mathrm{R} 12)^{42}$, in which the $\mathrm{H} \bullet$ formed via the reaction between $\mathrm{H}_{2} \mathrm{O}$ and $\equiv \mathrm{Si} \bullet(\mathrm{R} 13)^{43}$. The continuously generated $\mathrm{HO}_{2} \bullet$ then gradually transformed to $\mathrm{H}_{2} \mathrm{O}_{2}$ in half-quantity cycling between $\mathrm{R} 10$ and $\mathrm{R} 12$, in which the dissolved $\mathrm{O}_{2}$ was reduced to half of its initial amount in each cycle, concomitant with the generation of an equivalent molar amount of $\mathrm{H}_{2} \mathrm{O}_{2}$. Meanwhile, as predicted by Henry's law, $\sim 15 \%$ dissolved $\mathrm{O}_{2}$ might escape from the quartzwater interface to the headspace of the oxygen-free atmosphere (See Supplementary Text).

$$
\begin{gathered}
\equiv \mathrm{Si}^{+} \mathrm{O}_{2}^{--}+\mathrm{H}_{2} \mathrm{O}_{2} \rightarrow \equiv \mathrm{SiOH}+\bullet \mathrm{OH}+\mathrm{O}_{2} \\
\mathrm{H} \bullet+\mathrm{O}_{2} \rightarrow \mathrm{HO}_{2} \bullet
\end{gathered}
$$




$$
\equiv \mathrm{Si} \bullet+\mathrm{H}_{2} \mathrm{O} \rightarrow \equiv \mathrm{SiOH}+\mathrm{H} \bullet
$$

During the third stage (120-240 min), the concentrations of $\mathrm{H}_{2} \mathrm{O}_{2}$ approached steady values, and the concentration of the dissolved $\mathrm{O}_{2}$ decreased to $<0.01 \mathrm{mg} \mathrm{L}^{-1}$. This indicates that most SBRs were consumed in the quartz-water interface reactions. The production of both $\bullet \mathrm{OH}$ and $\mathrm{H}_{2} \mathrm{O}_{2}$ was restricted by the quantity of SBRs as the concentration of the ROS was linearly correlated to the particle loading (Supplementary Fig. 3). About $47.13 \%$ of $\mathrm{H}_{2} \mathrm{O}_{2}$ was derived from reactions between $\equiv \mathrm{SiOO}$. and water, while the remainder of the $\mathrm{H}_{2} \mathrm{O}_{2}$ was formed via the recombination of $\bullet \mathrm{OH}$ (Supplementary Fig. 4). In addition, the surplus $\mathrm{H}$ • combined with each other to form $\mathrm{H}_{2}$ and escaped to the headspace (Supplementary Fig. 5).

Further, we confirmed that the intermediate $\mathrm{O}_{2}$ in the reaction system could convert to ROS via the following two conditions. When quartz was ground in the presence of $\mathrm{O}_{2}$, both the yielding of $\bullet \mathrm{OH}$ and $\mathrm{H}_{2} \mathrm{O}_{2}$ in the suspensions under various $\mathrm{pH}$ values were greater than those of quartz ground in an $\mathrm{O}_{2}$-free atmosphere (Supplementary Fig. 6a). The increased ROS production was attributed to a higher proportion of oxygenic SBRs that were formed via the interaction between the initial SBRs and atmospheric $\mathrm{O}_{2}$ as per R14 ${ }^{44}$. On the other hand, an increase in the pre-existing dissolved $\mathrm{O}_{2}$ concentration in water could enhance the production of $\mathrm{H}_{2} \mathrm{O}_{2}$ while having little effect on that of $\bullet \mathrm{OH}$ (Supplementary Fig. $6 \mathrm{~b}$ ), as depicted in R12 and R10.

$$
\equiv \mathrm{Si \bullet}+\mathrm{O}_{2} \rightarrow \equiv \mathrm{SiOO} \bullet
$$

Continuous generation of ROS in hydrodynamic environments with the abrasions of quartz. Although our experiments show that $1 \mathrm{~m}^{2}$ of abraded quartz surfaces could yield $9.65 \mathrm{nmol}$ of $\mathrm{H}_{2} \mathrm{O}_{2}$ at a rate of ca. $1.95 \times 10^{11}$ molecules $\mathrm{cm}^{-2} \mathrm{~s}^{-1}$ (Fig. $2 \mathrm{a}$ and Supplementary Figs. 3 and 7), the true ROS release rate in nature is dependent on the intensity and extent of abrasion. We experimentally simulated the dynamic abrasion of quartz to mimic the conditions that quartz grains would undergo in coastal zones subject to waves and tides (Supplementary Fig. 8 and Video). Being ground mildly in a tumbling barrel, the particle size of quartz gradually decreased and the initially clear water became cloudy. The newly produced quartz surfaces kept increasing in a near-linear manner, which indicated that $129.75 \mathrm{~m}^{2}$ of surface area could be produced by abrading $1 \mathrm{~g}$ of quartz for 1 year. Based on the laboratory abrasion rate of quartz and the subsequent $\mathrm{H}_{2} \mathrm{O}_{2}$ yield per unit area, the simulated $\mathrm{H}_{2} \mathrm{O}_{2}$ production rate is calculated to be $2.39 \times 10^{10}$ molecules $\mathrm{g}^{-1} \mathrm{~s}^{-1}$.

The EPR spectra displayed signals of spin adducts of radicals, including $\cdot \mathrm{OH}, \cdot \mathrm{O}_{2}^{-}$(superoxide radical) and ${ }^{1} \mathrm{O}_{2}$ (singlet oxygen) during the time-course of quartz abrasion (Fig. 3). Additionally, the intensity of these signals increased along with the abrading time. These observations further support that ROS and $\mathrm{O}_{2}$ could be continuously generated in aqueous environments with strong hydrodynamic processes.

The $\mathrm{H}_{2} \mathrm{O}_{2}$ flux and the resultant redox evolution in the Archean. Our results reveal a geochemical pathway for the generation of ROS and free oxygen at the quartz-water interface in aquatic environments that has not been previously described. As these reactions occurred naturally in the geological past, it stands to reason that a stable and persistent source for ROS and $\mathrm{O}_{2}$ was generated in subaqueous conditions in the absence of biological processes, such as oxygenic photosynthesis. Crucially, with a higher yield and better accessibility, this oxygen-producing pathway not only provided a favorable source of $\mathrm{H}_{2} \mathrm{O}_{2}$, but the $\mathrm{O}_{2}$ ultimately produced would have exerted a new evolutionary pressure to early anoxygenic photosynthesizers ${ }^{6}$.

We extrapolated our experimental results to depositional scale and calculated the $\mathrm{H}_{2} \mathrm{O}_{2}$ flux in the turbulent subaqueous environments. Our calculations show that an Archean river carrying a heavy load of suspended sediments could potentially transport $\mathrm{H}_{2} \mathrm{O}_{2}$ to the oceans at a flux of $5.81 \times 10^{14}$ molecules $\mathrm{cm}^{-2} \mathrm{~s}^{-1}$, while the in-situ flux of $\mathrm{H}_{2} \mathrm{O}_{2}$ at the Archean delta/shore could additionally reach to $4.87 \times 10^{11}$ molecules $\mathrm{cm}^{-2} \mathrm{~s}^{-1}$ (See Supplementary Text and Fig. 9). To further put these numbers into perspective, we compared our results with two endmember $\mathrm{O}_{2-}$ producing reactions: atmospheric photochemical processes (minimum value) and benthic cyanobacterial mats (maximum value). In the case of the former, our calculations suggest that in such coastal environments, atmospheric photochemical processes could yield $5 \times 10^{5}$ molecules $\mathrm{O}_{2} \mathrm{~cm}^{-2} \mathrm{~s}^{-1}$ ) (based on R2). By contrast, a literature survey of $84 \mathrm{in}$-situ measurements of oxygenic photosynthesis in benthic microbial ecosystems showed that depthintegrated net rates $\left(\mathrm{O}_{2}\right.$ produced $-\mathrm{O}_{2}$ immediately consumed) are log-normally distributed and generally fall within two orders of magnitude $\left(10^{0}-10^{-2} \mathrm{nmol} \mathrm{cm}^{-2} \mathrm{~s}^{-1}\right)$ regardless of the benthic environment ${ }^{45}$. With this range in mind, those authors adapted the median net $\mathrm{O}_{2}$ production rate of $0.16 \mathrm{nmol} \mathrm{cm}{ }^{-2} \mathrm{~s}^{-1}$ or $9.63 \times 10^{13}$ molecules $\mathrm{cm}^{-2} \mathrm{~s}^{-1}$. This rate of $\mathrm{O}_{2}$ production from modern cyanobacterial mats is $\sim 400$ times higher than the in-situ flux of $\mathrm{O}_{2}$ at the Archean delta/shore $\left(2.44 \times 10^{11}\right.$ molecules $\mathrm{cm}^{-2} \mathrm{~s}^{-1}$; based on $\mathrm{R} 2$ and using the in-situ $\mathrm{H}_{2} \mathrm{O}_{2}$ production rate of $4.87 \times 10^{11}$ molecules $\mathrm{cm}^{-2} \mathrm{~s}^{-1}$ ). However, it clearly demonstrates that the abrasion of quartz sands in hydrodynamic processes can act as a geologically significant oxygen-producing pathway.

Such high yielding of oxidants could have created locally oxidized environments that not only were detrimental to the early anaerobic photoautotrophs growing within the microbial mats, but the $\mathrm{O}_{2}$ would eventually have expanded into the water column and readily eliminated the reductants necessary for anaerobic photosynthesis by planktonic communities (e.g., $\mathrm{H}_{2}$, $\left.\mathrm{HS}^{-}, \mathrm{Fe}^{2+}\right)$. We modeled how this $\mathrm{O}_{2}$ first effected the photosynthetic communities growing within a mat, and then extrapolated to the water column above the continental shelf. In terms of the microbial mats, $\mathrm{O}_{2}$ generation would have presented a challenge to microbial metabolism that used electron donors that are readily oxidized. Most cyanobacteria are sensitive to sulfide as it directly inhibits the water-splitting reaction of Photosystem II (PSII) ${ }^{46}$. Even in metabolically versatile cyanobacteria mats, with a $\mathrm{H}_{2} \mathrm{~S}$ concentration as low as $1 \mu \mathrm{M}$, the oxygenic photosynthesis is severely inhibited and replaced by sulfide-oxidizing anoxygenic photosynthesis ${ }^{47,48}$. With the depletion of sulfide by diffusing $\mathrm{O}_{2}$, the onset of oxygenic photosynthesis can occur, then the competition with the two metabolisms (anoxygenic photosynthesis and chemosynthesis) is possible.

In the case of the water column, and taking water-soluble $\mathrm{Fe}(\mathrm{II})$ as an example, it has been proposed that the oldest banded iron formations (BIF) were formed via the activity of anoxygenic photosynthetic bacteria, the photoferrotrophs ${ }^{49,50}$. These bacteria might have grown throughout the photic zone prior to cyanobacterial evolution, but thereafter were progressively marginalized to greater depths as the photic zone became more oxygenated ${ }^{51}$. Using a quantitative model modified from McKay and Hartman 6 , we performed the time evolution of $\mathrm{H}_{2} \mathrm{O}_{2}$ concentration in the oxic zone and the length of the pathway to which oxic conditions extend into the Archean shallow seawater near deltas and shores based on the two $\mathrm{H}_{2} \mathrm{O}_{2}$ flux calculated above (Supplementary Figs. 9-10). The continuing source of ROS and $\mathrm{O}_{2}$ can produce an oxidized front moving 


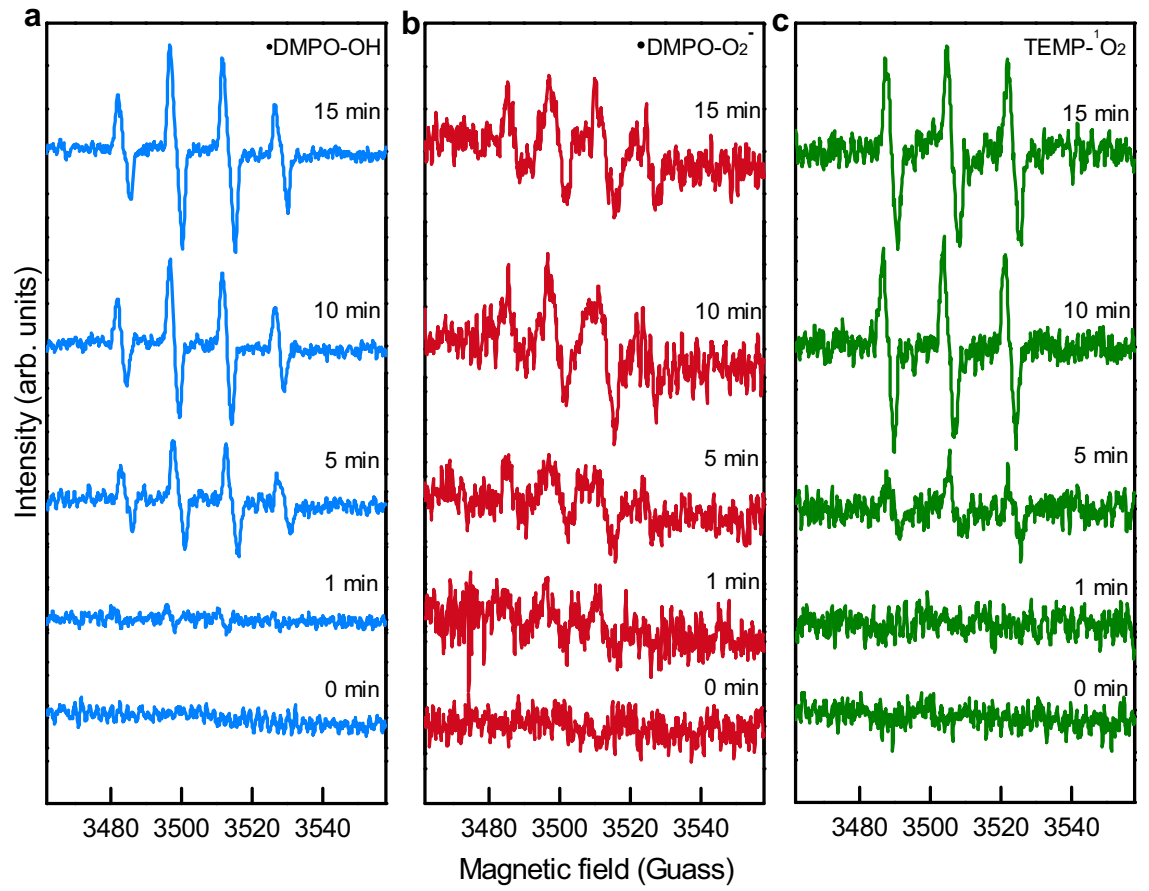

Fig. 3 Continuous generation of $\bullet \mathrm{OH}_{1} \cdot \bullet \mathbf{O}_{\mathbf{2}}^{-}$, and $\mathbf{1}^{\mathbf{1}} \mathbf{O}_{\mathbf{2}}$ during dynamic fracturing processes of quartz in aquatic environments. The characterized $E P R$ signals of $\bullet \mathrm{OH}, \bullet \mathrm{O}_{2}^{-}$, and ${ }^{1} \mathrm{O}_{2}$ spin adducts occur and grow with increased ball-milling time (0-15 min). a Hydroxyl radical $(\bullet \mathrm{OH})$ spin adducts $(\bullet D M P O-$ $\mathrm{OH})$, a 4 -fold characteristic peak with an intensity ratio of 1:2:2:1. b Superoxide radical $\left(\bullet \mathrm{O}_{2}{ }^{-}\right)$spin adducts $\left(\bullet D M P O-\mathrm{O}_{2}-\right)$, a 4 -fold characteristic peak with an intensity ratio of 1:1:1:1. c Singlet oxygen $\left({ }^{1} \mathrm{O}_{2}\right)$ spin adducts $\left(\bullet \operatorname{TEMP}^{-1} \mathrm{O}_{2}\right)$, three peaks with an intensity ratio of 1:1:1.

outward from the delta to the open ocean that was characterized by ferruginous seawater ${ }^{52}$.

The $\mathrm{H}_{2} \mathrm{O}_{2}$-driving evolution of photosynthesis. The $\mathrm{O}_{2}$ levels within the oxic zone are several orders higher than the threshold stimulating the development of oxygen tolerance (e.g., superoxide dismutase, $\mathrm{Mn}$ catalase) and aerobic respiration (dissolved $\mathrm{O}_{2}>3 \mathrm{nM}$ ) in the anoxygenic phototrophs ${ }^{6,22,53}$. Furthermore, it provides the indispensable oxidizing species (i.e., $\mathrm{O}_{2}$ and $\mathrm{H}_{2} \mathrm{O}_{2}$ ) for the key evolution of oxygenic photosynthesis. Due to the catalysation of aerobic cyclase enzyme in the organisms, the mechanical/chemically produced $\mathrm{O}_{2}$ could have served as the earliest external substrate for the $\mathrm{O}_{2}$-dependent biosynthesis of chlorophyll- $a$ precursor Mg-divinyl chlorophyllide ${ }^{54,55}$. In summary, the primitive PSII composed of an intermediate pigment of chlorophyll- $a$ and an original $\mathrm{Mn}_{2}$-cluster (e.g., the Mn catalase or $\mathrm{MnO}_{2}$ minerals) would have allowed the ancestral cyanobacteria to extract two electrons from $\mathrm{H}_{2} \mathrm{O}_{2}$ (the transitional electron donors) at a time, liberating the earliest biogenic $\mathrm{O}_{2}$ (R2) $1,11,55,56$.

Phylogenetic analyses of the early evolution of the ROS gene network proteins suggest that superoxide dismutase, catalase, and peroxiredoxins evolved in the presence of ROS $\sim 4.1-3.6 \mathrm{Gyr}$ $\mathrm{ago}^{57}$, well before the geochemical evidence of the rise of oxygenevolving photosynthetic cyanobacteria ${ }^{58-60}$. These ROSscavenging enzymes might have emerged in the initial adaptation to the weakly oxic environments and crucially protected the earliest cyanobacteria from the toxicity of $\operatorname{ROS}^{61}$. Notably, the rise in both oxygenases and other oxidoreductases suggests a wider availability of trace oxygen $\sim 3.1 \mathrm{Gyr}^{25}$. Following on from this, we propose that the early evolution of oxygenic photosynthesis might have originated as benthic microbial communities at river or coastal setting ${ }^{45,56}$. In such high-energy hydrodynamic environments, the continuous abrasion of quartz-bearing sediment provided a high yield of oxidants despite the contemporary atmosphere being anoxic $\left(\mathrm{O}_{2}<10^{-7} \mathrm{~atm}^{62}\right)$. This process would have operated independent of atmospheric conditions, similar to the benthic pre-GOE oxygen oases previously proposed ${ }^{45}$. Moreover, in the absence of plant root systems, Archean surface terrains would have been subject to rapid migration of riverbeds and a predisposition for wide, braided streams to transport and disperse the large volumes of supermature quartz-rich sands weathered from the source terrains ${ }^{63}$. Subjected to much more intense tidal erosion than today ${ }^{64}$, the Archean land surface would have experienced enhanced wetting, conditions favouring colonization by microbial mats. With the mechanically resistant and sandy biolaminae shielding the harmful ultraviolet light, the ancestral cyanobacteria could perform photosynthesis via the $\mathrm{H}_{2} \mathrm{O}_{2}$ delivered by currents waves and tides associated with these high-energy environments (Fig. 4a).

It is perhaps unsurprising then that some of the best evidence for Archean life comes from the $3.22 \mathrm{Gyr}$ Moodies Group in South Africa, where extensive microbial mats draped fluvial conglomerates, gravelly sandstones, and shallow marine siliciclastic tidal deposits ${ }^{65,66}$. Wavy and crinkly carbonaceous laminations within these gravelly sandstones, and on top of the conglomerate beds, are often bent upwards and plastically deformed by subvertical fluid-escape structures which indicate their cohesive water-impermeable nature and synsedimentary origin. Petrographic analysis further reveals that during periods of increased current velocity, laminae were partially eroded, ripped up, and reworked as fragments up to several centimetres in length. Although not conclusive of cyanobacteria, $\delta^{13} \mathrm{C}_{\text {org }}$ values ranging between $-23.6 \%$ and $-17.9 \%$ are consistent with the Calvin-Benson cycle, while $\delta^{15} \mathrm{~N}$ values of the terrestrial mats with a mean of $+4.3 \%$ are suggestive of partial nitrification and/ or denitrification 66 , both of which require oxidative nitrogen cycling in the presence of free oxygen in the mats ${ }^{66,67}$. Moreover, the contemporaneous S-isotopic compositions in the Moodies 

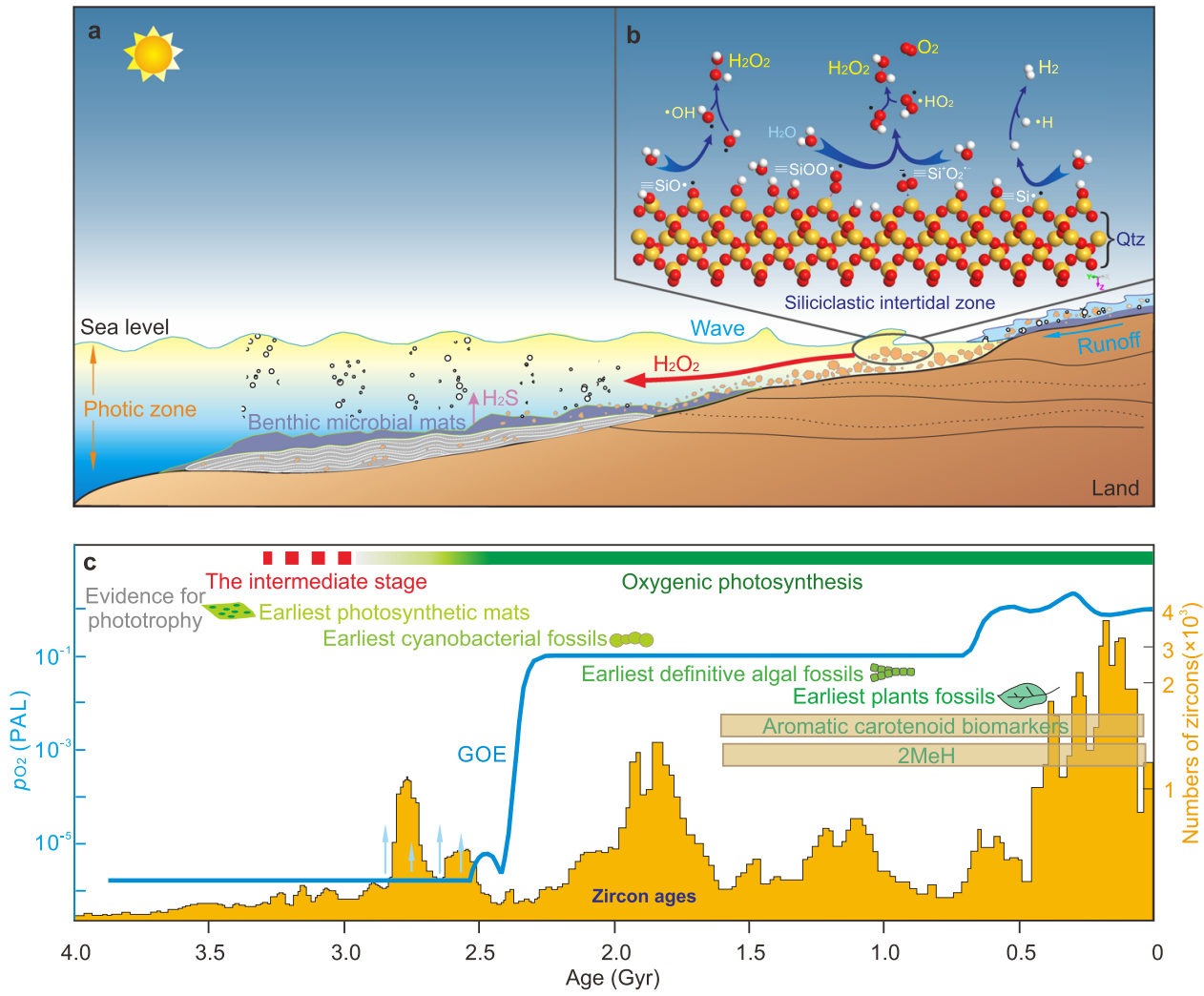

Fig. 4 A plausible origin of oxygenic photosynthesis from an anaerobic photosynthetic community with the supply of $\mathrm{H}_{2} \mathrm{O}_{2}$ released at mineral-water interface along the siliciclastic intertidal zone. a The $\mathrm{H}_{2} \mathrm{O}_{2}$-induced evolutionary impetus on the organisms that conduct anoxygenic photosynthesis in microbial mats. $\mathbf{b ~} \mathrm{H}_{2} \mathrm{O}_{2}$ generated at the quartz-water interface in the high-energy hydrodynamic intertidal zone. c Geological constraints on the origin of oxygenic photosynthesis including data from the body and molecular fossil (lipid biomarker) records, the age distribution of zircons and the oxygen concentration relative to the present atmospheric level (PAL). Modified from Fischer ${ }^{4}$, Lyons ${ }^{58}$, and Hawkesworth ${ }^{69}$.

Group barites also suggest some pyrite weathering under weakly oxidizing conditions ${ }^{68}$.

Our hypothesis neatly ties together a significant source of abiotic oxygen on the Archean Earth and the subsequent evolution of oxygenic photosynthesis. As more quartz-rich rocks (such as tonalite-trondhjemite-granodiorite) emerged in the continental landmass of the Archean ${ }^{69}$ (Fig. 4b), the quartz-rich rocks suffered aggressive erosion during fluvial transport to the coast. The increased oxidation (via $\mathrm{H}_{2} \mathrm{O}_{2}$ and $\mathrm{O}_{2}$ ) placed an increasing evolutionary pressure on the anaerobic microbial world. Eventually, as the ancestral cyanobacteria developed oxygenic photosynthesis and gained the ability for extracting electrons from $\mathrm{H}_{2} \mathrm{O}^{1,56,70}$, they would have outcompeted the anaerobes that were constrained by a limited geological supply of reductant electron donors ${ }^{71}$. This shift in photosynthesis ultimately changed the structure of the Archean Earth's biosphere and initiated oxidative weathering on land ${ }^{45,72}$. Our study does not constrain the time when oxygenic photosynthesis successfully evolved but it does provide a plausible scenario for the initial development of oxygenation on the early Earth. Significantly, from a geochemical perspective, this means that some existing Archean proxies of $\mathrm{O}_{2}$ are not necessarily tied to early oxygenic photosynthesis.

\section{Methods}

Sample preparation and storage. Quartz sands were purchased from Richjoint (Shanghai, China; $\mathrm{SiO}_{2}>99$ wt.\%). The quartz raw material was mesh-sieved and followed by a hydrofluoric acid (10 wt.\%) washing for $8 \mathrm{~h}$ to remove surface impurities and produce the surface without dangling bonds $(\mathrm{QW})^{28}$. The $0.25-0.6 \mathrm{~mm}$ quartz particles were chosen and washed with distilled deionized water for a few times until the $\mathrm{pH}$ of the cleaning solution reached neutral, then dried in oven at $110^{\circ} \mathrm{C}$ for $24 \mathrm{~h}$ and stored in a glovebox for further experiments $\left(\mathrm{N}_{2}>99.999 \%, \mathrm{H}_{2} \mathrm{O}<0.1 \mathrm{ppm}, \mathrm{O}_{2}<0.1 \mathrm{ppm}\right.$, Mikrouna).

In the glovebox, the quartz samples were loaded into a zirconia ceramic jar with two inlet switches, and sealed tightly with a gasket ring and screw fasteners. Then, the jar was filled with the same atmosphere as in the glovebox before being transferred to a planetary ball mill (Fritsch, Pulverisette 6) for grinding at $350 \mathrm{rpm}$ for 1 and $5 \mathrm{~h}$, respectively. After grinding, the jar was moved back to the glovebox, and the abraded quartz samples (QGN-1h and QGN-5h) were collected and sealed in glass bottles in the glovebox to protect the surface reactive sites.

A control sample was ground in a pure $\mathrm{O}_{2}$ atmosphere for $5 \mathrm{~h}$ with the following procedure: first, quartz powders were loaded into the jar in the glovebox and the jar was sealed tightly with the aforementioned procedure. Then, the jar was moved out of the glovebox and vacuumed through one inlet with a mechanical pump, and the jar was filled with pure oxygen $(>99.99 \%)$ for grinding by the aforementioned procedure. Lastly, the sample was transferred to glass bottles in a glass desiccator full-filled with ultrapure $\mathrm{N}_{2}$. This sample was used in the according experiments within $48 \mathrm{~h}$ after grinding.

Experimental procedures. All waters used in the experiments were deionized to $18.2 \mathrm{M} \Omega \mathrm{cm}^{-1}$ at $25^{\circ} \mathrm{C}$. The waters with a range of dissolved oxygen contents $\left(\mathrm{DO}=0.01,0.64,1.28\right.$, and $4.10 \mathrm{mg} \mathrm{L}^{-1}$, respectively) were prepared by diluting the high DO $\left(9.00 \mathrm{mg} \mathrm{L}^{-1}\right)$ water with low DO $\left(<0.01 \mathrm{mg} \mathrm{L}^{-1}\right)$ water. Potassium phosphate buffer solutions of various $\mathrm{pH}$ values $(\mathrm{pH}=4.0,6.0,7.0$, and 7.4) were prepared by mixing $1 / 15 \mathrm{M} \mathrm{KH}_{2} \mathrm{PO}_{4}$ with $1 / 15 \mathrm{M} \mathrm{K}_{2} \mathrm{HPO}_{4}$ solutions with according ratios.

Measurements of the reaction kinetics of ROS generation were conducted in the glovebox at room temperature. A $250-\mathrm{mL}$ solution $\left(\mathrm{DO}<0.01 \mathrm{mg} \mathrm{L}^{-1}\right)$ with $10 \mathrm{mM}$ benzoic acid (BA, Aladdin, the trapping agent for hydroxyl radical $(\bullet \mathrm{OH})$ ) was prepared and transferred to a three-neck flask with continuous magnetic stirring. Probes were then put into the solution through the flask necks to measure the $\mathrm{pH}$ values (Mettler-Toledo FiveEasy PlusTM), DO, and redox potentiality (HQ40, HACH), respectively. When $20.00 \mathrm{~g}$ of QGN-5h (the specific surface area is $5.21 \mathrm{~m}^{2} \mathrm{~g}^{-1}$ ) was quickly plunged into the solution, the reaction started and lasted for $4 \mathrm{~h}$. In all, $4.00 \mathrm{~mL}$ of suspension was extracted and filtered through a $0.22-\mu \mathrm{m}$ membrane (Jinteng) at each sampling time $(0,1,5,10,15,20,30,45,60,90,120$, 150,180 , and $240 \mathrm{~min}$, respectively). These subsamples were used for measuring the concentrations of hydroxyl radical and hydrogen peroxide. 
To examine the effects of atmosphere and aquatic chemistry on the production of ROS, suspensions were prepared by submerging the abraded quartz sample $(1.00 \mathrm{~g})$ into the deionized water $(5.00 \mathrm{~mL})$ with magnetic stirring. The QGN-5h sample was added into the water with various concentrations of dissolved $\mathrm{O}_{2}$. The quartz samples ground under different headspace gases $\left(\mathrm{N}_{2}\right.$ or $\left.\mathrm{O}_{2}\right)$ were then mixed with $5.00 \mathrm{~mL}$ of potassium phosphate buffer solutions that were previously prepared under various $\mathrm{pH}$ conditions $\left(\mathrm{DO}<0.01 \mathrm{mg} \mathrm{L}^{-1}\right)$. The filtered liquid samples were collected for measuring the concentrations of hydroxyl radical and hydrogen peroxide.

To further examine the effect of specific surface area on the production of ROS, the loading of quartz (i.e., the ratio of solid mass to water volume $\left(\mathrm{DO}<0.01 \mathrm{mg} \mathrm{L}^{-1}\right)$ ) was set at $0.10,0.20,0.40,0.60,0.80$, and $1.00 \mathrm{~g} \mathrm{~mL}^{-1}$, respectively. All filtered liquid samples from the batch experiments were collected for ROS measurements.

To confirm the presence of $\equiv \mathrm{SiOO} \bullet$ on the surface of the abraded quartz produced in anoxic conditions, we conducted control experiments by scavenging specific radicals. Methanol was chosen as the $\bullet \mathrm{OH}$ scavenger, while benzoquinone was used to scavenge $\bullet \mathrm{O}_{2}{ }^{-} / \mathrm{HO}_{2} \cdot$ (Burns et al. ${ }^{73}$ ). In total, $1.00 \mathrm{~g}$ of the abraded quartz sample (QGN-5h) was plunged into $5.00 \mathrm{~mL}$ of the solution (DO $<0.01 \mathrm{mg} \mathrm{L}^{-1}$ ) with $2 \mathrm{mM}$ the ROS scavenger (methanol or benzoquinone) with magnetic stirring. All filtered liquid samples were collected to measure the concentrations of $\mathrm{H}_{2} \mathrm{O}_{2}$.

To experimentally test if ROS could be continuously produced in the natura erosion of quartz by waves and tides, a tumbling barrel was used to grind quartz (Supplementary Fig. 8a-b). Such an apparatus has been used to simulate the fluvial abrasion of small pebbles and sands in laboratory 74,75 . The solid concentration (quartz sands with a size of ca. $2 \mathrm{~mm}$ ) is set to $250 \mathrm{~kg} \mathrm{~m}^{-3}$, and the tumbling barrel was rolling at $1 \mathrm{~m} \mathrm{~s}^{-1}$. About $10 \mathrm{~mL}$ of the suspension was sampled at 24, 48, 72, 96 , and $120 \mathrm{~h}$, respectively. After centrifugation and drying, the quartz powders were collected for surface area measurements.

EPR spin trapping techniques were used to examine the transient radicals generated during the dynamic fracturing process of quartz. Probes with specific spin were selected to react with transient free radicals ${ }^{73}$. Hydroxyl radical $(\cdot \mathrm{OH})$, superoxide radical $\left(\cdot \mathrm{O}_{2}^{-}\right)$, and singlet oxygen $\left({ }^{1} \mathrm{O}_{2}\right)$ were trapped by DMPO $(5,5-$ dimethyl-1-pyrroline $\mathrm{N}$-oxide), DMPO/DMSO (dimethyl sulfoxide), and TEMP (2,2,6,6-tetramethylpiperidine), respectively, to form more stable spin adducts for quantification. In all, $1.00 \mathrm{~g}$ of quartz sand was ground in $2.00 \mathrm{~mL}$ of solutions containing the trapping agent $(10 \mathrm{mM})$ by vibrating ball mill (Pulverisette 23 MiniMill). After shaking at $50 \mathrm{~Hz}$ frequency for certain times $(0,1,5,10$, and $15 \mathrm{~min})$, $0.50 \mathrm{~mL}$ of the suspension containing spin adducts was sampled and filtered for EPR measurements.

The headspace gas composition in the jar during the quartz grinding process was monitored. In total, $30.00 \mathrm{~g}$ of quartz sands and $10.00 \mathrm{~mL}$ water (DO $<0.01 \mathrm{mg} \mathrm{L}^{-1}$ ) were loaded into the jar in the glovebox. The sealed jar filled with the same atmosphere as in the glovebox (i.e., ultrapure $\mathrm{N}_{2}$ ) was taken out, and transferred to a planetary ball mill (Fritsch, Pulverisette 6) for grinding at $350 \mathrm{rpm}$ for certain times $(0,0.5,1,1.5,2,2.5,3$, and $5.5 \mathrm{~h})$. In total, $1.50 \mathrm{~mL}$ gas in the headspace of the jar was extracted with a syringe from the valve with a thick silicone pad for gas content measurement in each interval.

Characterization of the crystallography of quartz. XRD patterns were obtained over the $2 \theta$ range from 3 to $70^{\circ}$ on a Bruker D8 ADVANCE X-ray diffractometer, operated at $40 \mathrm{kV}$ and $40 \mathrm{~mA}$ with $\mathrm{Cu} \mathrm{Ka}$ radiation. The scanning step was $3^{\circ} \mathrm{min}^{-1}$ $(2 \theta)$.

Surface area measurements were performed with the BET $\mathrm{N}_{2}$ technique. Nitrogen adsorption-desorption measurements were conducted at $77 \mathrm{~K}$ using an ASAP 2020 Surface Area \& Pore Size Analyzer (Micromeritics Instrument Corporation). Prior to the measurement, samples were degassed in vacuum at $200^{\circ} \mathrm{C}$ for $12 \mathrm{~h}$.

Characterization of the particle size and morphology of quartz. The particle size of the quartz powder (QGN-5h) was measured with a laser particle analyser (Chengdujingxin, JL-1177). The morphology of the quartz powder (QGN-5h) was observed with a scanning electron microscope (SEM, Phenom XL).

Measurements of surface-bound radicals. Surface-bound radicals formed via grinding were measured by EPR on a Bruker A300-10-12 spectrometer. The settings for the EPR measurements were as follows: center field, 3320G; sweep width, $500 \mathrm{G}$; microwave frequency, $9.297 \mathrm{GHz}$; modulation frequency, $100 \mathrm{kHz}$; power, $1.0 \mathrm{~mW}$; and temperature, $77 \mathrm{~K}$.

Measurements of headspace gas products. The gas products in the headspace of the sealed jar - after the quartz sands were ground in water - was determined by gas chromatography (GC, Agilent Technologies 7890-0322). Each gas sample was injected into the GC inlet connected with a vacuum glass system. The gas analyser included two thermal conductivity detectors for the analysis of permanent gases and a flame ionization detector for the analysis of hydrocarbon gases, as well as five rotary valves and seven columns. This enabled the analysis of all gaseous components with a single injection.
Measurements of hydroxyl radicals. All experiments were carried out at $25 \pm 2{ }^{\circ} \mathrm{C}$ in the dark. Quartz samples were mixed with the solutions containing the -OH trapping agent (benzoic acid, $\mathrm{BA}, 10 \mathrm{mM}$ ), then filtered and sampled for $\bullet \mathrm{OH}$ measurements by determining the concentrations of the oxidative product ( $p$ Hydroxybenzoic acid, $p$-HBA) of benzoic acid $(\mathrm{BA})^{76}$. For the determination of $p$ $\mathrm{HBA}, 1.00 \mathrm{~mL}$ of a filtered liquid sample was rapidly mixed with $1.00 \mathrm{~mL}$ methanol (chromatographic grade, J\&K Chemical) to quench further oxidation caused by -OH. The $p$-HBA concentration was measured by a high-performance liquid chromatography (HPLC, Agilent 1260) equipped with a UV detector and an Inter Sustain C18 column $(4.6 \times 250 \mathrm{~mm})$. The mobile phase was a mixture of $0.1 \%$ trifluoroacetic acid aqueous solution and acetonitrile $(65: 35, \mathrm{v}: \mathrm{v})$ at a flow rate of $1.00 \mathrm{~mL} \mathrm{~min}^{-1}$. The volume of sample injection was $20 \mu \mathrm{L}$, the column temperature was $30^{\circ} \mathrm{C}$, and the detection wavelength of UV was set at $255 \mathrm{~nm}$. The $p$-HBA retention time was $3.2 \pm 0.2 \mathrm{~min}$. The detection limit of $p$-HBA was optimized to $0.01 \mu \mathrm{M}$, which corresponds to $0.059 \mu \mathrm{M} \cdot \mathrm{OH}$.

Measurements of hydrogen peroxide. The $\mathrm{H}_{2} \mathrm{O}_{2}$ concentration was determined using a modified version of Leuco Crystal Violet (LCV, spectrographic grade, John Long) technique optimized for UV-Vis measurements ${ }^{77}$. LCV can be oxidized by - $\mathrm{OH}$ generated from $\mathrm{H}_{2} \mathrm{O}_{2}$ with the catalysis of the enzyme horseradish peroxidase (HRP, type III, $>300$ units $\mathrm{g}^{-1}$, Aladdin). The oxidizing product of LCV is crystal violet cation $\left(\mathrm{CV}^{+}\right)$, which has a spectrophotometric absorbance maximum at $590 \mathrm{~nm}$. The absorbance of $\mathrm{CV}^{+}$was measured on a Shunyuhengping UV2400 spectrometer.

Reagents (all stored at $4{ }^{\circ} \mathrm{C}$ and brought up to room temperature of $25 \pm 2{ }^{\circ} \mathrm{C}$ before analysis) were added to $1.70 \mathrm{~mL}$ filtered liquid sample in the following order for a total volume of $2 \mathrm{~mL}: 200 \mu \mathrm{L} 100 \mathrm{mM} \mathrm{KH}_{2} \mathrm{PO}_{4}$ (Aladdin) as $\mathrm{pH}$ buffer, $50 \mu \mathrm{L}$ $41 \mathrm{mM} \mathrm{LCV}$ (dissolved with $\mathrm{HCl}$ ), and $50 \mu \mathrm{L} 0.5 \mathrm{mg} \mathrm{mL}^{-1} \mathrm{HRP}$ (containing $1.5 \mathrm{mM}$ azide from Aladdin to prevent bacterial growth). After shaking to homogenize the samples, they were kept in dark at room temperature $\left(25 \pm 2{ }^{\circ} \mathrm{C}\right)$ for $30 \mathrm{~min}$ to stabilize the absorbance. Absorbance measurements were taken in $1 \mathrm{~cm}$ path-length cuvettes.

\section{Data availability}

The authors declare that the main data supporting the findings of this study are available in the following Data Repository link: https://doi.org/10.17632/h7y9jdmpxp.1. Source data are provided with this paper.

\section{Code availability}

The code in this study is available at https://doi.org/10.5281/zenodo.5515787.

Received: 2 April 2021; Accepted: 21 October 2021; Published online: 16 November 2021

\section{References}

1. Blankenship, R. E. \& Hartman, H. The origin and evolution of oxygenic photosynthesis. Trends Biochem. Sci. 23, 94-97 (1998).

2. Raymond, J. \& Blankenship, R. The origin of the oxygen-evolving complex. Coord. Chem. Rev. 252, 377-383 (2008).

3. Olson, J. M. The evolution of photosynthesis. Science 168, 438-446 (1970).

4. Fischer, W. W., Hemp, J. \& Johnson, J. E. Evolution of oxygenic photosynthesis. Annu. Rev. Earth Planet. Sci. 44, 647-683 (2016).

5. Griffin, B. M., Schott, J. \& Schink, B. Nitrite, an electron donor for anoxygenic photosynthesis. Science 316, 1870-1870 (2007).

6. McKay, C. P. \& Hartman, H. Hydrogen peroxide and the evolution of oxygenic photosynthesis. Orig. Life Evol. Biosph. 21, 157-163 (1991).

7. Dismukes, G. C. et al. The origin of atmospheric oxygen on Earth: the innovation of oxygenic photosynthesis. Proc. Natl Acad. Sci. USA 98, 2170-2175 (2001)

8. Johnson, J. E. et al. Manganese-oxidizing photosynthesis before the rise of cyanobacteria. Proc. Natl Acad. Sci. USA 110, 11238-11243 (2013).

9. Xiong, J., Fischer, W. M., Inoue, K., Nakahara, M. \& Bauer, C. E. Molecular evidence for the early evolution of photosynthesis. Science 289, 1724-1730 (2000).

10. Cardona, T. A fresh look at the evolution and diversification of photochemical reaction centers. Photosynth. Res. 126, 111-134 (2015).

11. Allen, J. P. \& Williams, J. C. The evolutionary pathway from anoxygenic to oxygenic photosynthesis examined by comparison of the properties of Photosystem II and bacterial reaction centers. Photosynth. Res. 107, 59-69 (2011).

12. Sauer, K. \& Yachandra, V. K. A possible evolutionary origin for the $\mathrm{Mn}_{4}$ cluster of the photosynthetic water oxidation complex from natural $\mathrm{MnO}_{2}$ precipitates in the early ocean. Proc. Natl Acad. Sci. USA 99, 8631-8636 (2002). 
13. Liu, W. et al. Anoxic photogeochemical oxidation of manganese carbonate yields manganese oxide. Proc. Natl Acad. Sci. USA 117, 22698-22704 (2020).

14. Kasting, J. F., Liu, S. C. \& Donahue, T. M. Oxygen levels in the prebiological atmosphere. J. Geophys. Res. Oceans 84, 3097-3107 (1979).

15. Bhetanabhotla, M. N., Crowell, B. A., Coucouvinos, A., Hill, R. D. \& Rinker, R. G. Simulation of trace species production by lightning and corona discharge in moist air. Atmos. Environ. 19, 1391-1397 (1985).

16. Kormann, C., Bahnemann, D. W. \& Hoffmann, M. R. Photocatalytic production of hydrogen peroxides and organic peroxides in aqueous suspensions of titanium dioxide, zinc oxide, and desert sand. Environ. Sci. Technol. 22, 798-806 (1988).

17. Draganić, I. G., Bjergbakke, E., Draganić, Z. D. \& Sehested, K. Decomposition of ocean waters by potassium- 40 radiation $3800 \mathrm{Ma}$ ago as a source of oxygen and oxidizing species. Precambrian Res. 52, 337-345 (1991).

18. Lee, J. K. et al. Spontaneous generation of hydrogen peroxide from aqueous microdroplets. Proc. Natl Acad. Sci. USA 116, 19294-19298 (2019).

19. Kasting, J. F., Pollack, J. B. \& Crisp, D. Effects of high $\mathrm{CO}_{2}$ levels on surface temperature and atmospheric oxidation state of the early Earth. J. Atmos. Chem. 1, 403-428 (1984).

20. Haqq-Misra, J., Kasting, J. F. \& Lee, S. Availability of $\mathrm{O}_{2}$ and $\mathrm{H}_{2} \mathrm{O}_{2}$ on prephotosynthetic Earth. Astrobiology 11, 293-302 (2011).

21. Pecoits, E. et al. Atmospheric hydrogen peroxide and Eoarchean iron formations. Geobiology 13, 1-14 (2015).

22. Stolper, D. A., Revsbech, N. P. \& Canfield, D. E. Aerobic growth at nanomolar oxygen concentrations. Proc. Natl Acad. Sci. USA 107, 18755-18760 (2010).

23. Liang, M.-C., Hartman, H., Kopp, R. E., Kirschvink, J. L. \& Yung, Y. L. Production of hydrogen peroxide in the atmosphere of a Snowball Earth and the origin of oxygenic photosynthesis. Proc. Natl Acad. Sci. USA 103, 18896-18899 (2006).

24. Nhleko, N. The Pongola Supergroup in Swaziland (Rand Afrikaans University, 2004).

25. Jabłońska, J. \& Tawfik, D. S. The evolution of oxygen-utilizing enzymes suggests early biosphere oxygenation. Nat. Ecol. Evol. 5, 1-7 (2021).

26. Schoonen, M. A. A. et al. Mineral-induced formation of reactive oxygen species. Rev. Mineral. Geochem. 64, 179-221 (2006).

27. Hurowitz, J. A., Tosca, N. J., McLennan, S. M. \& Schoonen, M. A. A. Production of hydrogen peroxide in Martian and lunar soils. Earth Planet. Sci. Lett. 255, 41-52 (2007).

28. Fubini, B., Giamello, E., Volante, M. \& Bolis, V. Chemical functionalities at the silica surface determining its reactivity when inhaled. Formation and reactivity of surface radicals. Toxicol. Ind. Health 6, 571-598 (1990).

29. Heubeck, C. \& Lowe, D. R. Depositional and tectonic setting of the Archean Moodies Group, Barberton Greenstone Belt, South Africa. Precambrian Res. 68, 257-290 (1994).

30. Tossell, J. A. A comparison of silicon-oxygen bonding in quartz and magnesian olivine from X-ray spectra and molecular orbital calculations. Am. Mineral. 62, 136-141 (1977).

31. Schrader, R., Wissing, R. \& Kubsch, H. Zur Oberflächenchemie von mechanisch activiertem Quarz. Z. Anorg. Allg. Chem. 365, 191-198 (1969).

32. Fubini, B. \& Areán, C. O. Chemical aspects of the toxicity of inhaled mineral dusts. Chem. Soc. Rev. 28, 373-381 (1999).

33. Fubini, B. \& Hubbard, A. Reactive oxygen species (ROS) and reactive nitrogen species (RNS) generation by silica in inflammation and fibrosis. Free Radic. Biol. Med. 34, 1507-1516 (2003).

34. Cohn, C. A., Laffers, R., Simon, S. R., O'Riordan, T. \& Schoonen, M. A. Role of pyrite in formation of hydroxyl radicals in coal: possible implications for human health. Part. Fibre Toxicol. 3, 16 (2006).

35. Harrington, A. D., Tsirka, S. E. \& Schoonen, M. A. Quantification of particleinduced inflammatory stress response: a novel approach for toxicity testing of earth materials. Geochem. Trans. 13, 4 (2012).

36. Xu, J., Sahai, N., Eggleston, C. M. \& Schoonen, M. A. A. Reactive oxygen species at the oxide/water interface: Formation mechanisms and implications for prebiotic chemistry and the origin of life. Earth Planet. Sci. Lett. 363, 156-167 (2013).

37. Kaur, J. \& Schoonen, M. A. Non-linear hydroxyl radical formation rate in dispersions containing mixtures of pyrite and chalcopyrite particles. Geochim. Cosmochim. Acta 206, 364-378 (2017)

38. Farquhar, J., Bao, H. \& Thiemens, M. Atmospheric influence of Earth's earliest sulfur cycle. Science 289, 756-758 (2000).

39. Konhauser, K. O. et al. Aerobic bacterial pyrite oxidation and acid rock drainage during the Great Oxidation Event. Nature 478, 369-373 (2011).

40. Murashov, V. V. \& Demchuk, E. Surface sites and unrelaxed surface energies of tetrahedral silica polymorphs and silicate. Surf. Sci. 595, 6-19 (2005).

41. Fukuchi, T. A mechanism of the formation of $\mathrm{E}^{\prime}$ and peroxy centers in natural deformed quartz. Appl. Radiat. Isot. 47, 1509-1521 (1996).

42. Michael, J. V., Su, M.-C., Sutherland, J. W., Carroll, J. J. \& Wagner, A. F. Rate constants for $\mathrm{H}+\mathrm{O}_{2}+\mathrm{M} \rightarrow \mathrm{HO}_{2}+\mathrm{M}$ in seven bath gases. J. Phys. Chem. A 106, 5297-5313 (2002).
43. Kita, I., Matsuo, S. \& Wakita, H. $\mathrm{H}_{2}$ generation by reaction between $\mathrm{H}_{2} \mathrm{O}$ and crushed rock: An experimental study on $\mathrm{H}_{2}$ degassing from the active fault zone. J. Geophys. Res. Solid Earth 87, 10789-10795 (1982).

44. Bak, E. N. et al. Production of reactive oxygen species from abraded silicates. Implications for the reactivity of the Martian soil. Earth Planet. Sci. Lett. 473, 113-121 (2017).

45. Lalonde, S. V. \& Konhauser, K. O. Benthic perspective on Earth's oldest evidence for oxygenic photosynthesis. Proc. Natl Acad. Sci. USA 112, 995-1000 (2015).

46. Padan, E. Facultative anoxygenic photosynthesis in cyanobacteria. Annu. Rev. Plant. Biol. 30, 27-40 (1979).

47. Dick, G. J., Grim, S. L. \& Klatt, J. M. Controls on $\mathrm{O}_{2}$ production in cyanobacterial mats and implications for Earth's oxygenation. Annu. Rev. Earth Planet. Sci. 46, 123-147 (2018).

48. Liu, D. et al. Synechococcus sp. strain PCC7002 uses sulfide: quinone oxidoreductase to detoxify exogenous sulfide and to convert endogenous sulfide to cellular sulfane sulfur. Mbio 11, e03420-19 (2020).

49. Czaja, A. D. et al. Biological Fe oxidation controlled deposition of banded iron formation in the ca. 3770Ma Isua Supracrustal Belt (West Greenland). Earth Planet. Sci. Lett. 363, 192-203 (2013).

50. Martinez, R. E. et al. Surface reactivity of the anaerobic phototrophic Fe(II)oxidizing bacterium Rhodovulum iodosum: Implications for trace metal budgets in ancient oceans and banded iron formations. Chem. Geol. 442, 113-120 (2016).

51. Kappler, A., Pasquero, C., Konhauser, K. O. \& Newman, D. K. Deposition of banded iron formations by anoxygenic phototrophic Fe(II)-oxidizing bacteria. Geology 33, 865-868 (2005).

52. Konhauser, K. O. et al. Decoupling photochemical Fe(II) oxidation from shallow-water BIF deposition. Earth Planet. Sci. Lett. 258, 87-100 (2007).

53. Fischer, W. W., Hemp, J. \& Valentine, J. S. How did life survive Earth's great oxygenation? Curr. Opin. Chem. Biol. 31, 166-178 (2016).

54. Raymond, J. \& Blankenship, R. E. Biosynthetic pathways, gene replacement and the antiquity of life. Geobiology 2, 199-203 (2004).

55. Hohmann-Marriott, M. F. \& Blankenship, R. E. Evolution of photosynthesis. Annu. Rev. Plant Biol. 62, 515-548 (2011).

56. Blank, C. E. \& Sánchez-Baracaldo, P. Timing of morphological and ecological innovations in the cyanobacteria - a key to understanding the rise in atmospheric oxygen. Geobiology 8, 1-23 (2010).

57. Inupakutika, M. A., Sengupta, S., Devireddy, A. R., Azad, R. K. \& Mittler, R. The evolution of reactive oxygen species metabolism. J. Exp. Bot. 67, 5933-5943 (2016).

58. Lyons, T. W., Reinhard, C. T. \& Planavsky, N. J. The rise of oxygen in Earth's early ocean and atmosphere. Nature 506, 307-315 (2014).

59. Planavsky, N. J. et al. Evidence for oxygenic photosynthesis half a billion years before the Great Oxidation Event. Nat. Geosci. 7, 283-286 (2014).

60. Crowe, S. A. et al. Atmospheric oxygenation three billion years ago. Nature 501, 535-538 (2013).

61. Ślesak, I., Ślesak, H. \& Kruk, J. Oxygen and hydrogen peroxide in the early evolution of life on Earth: In silico comparative analysis of biochemical pathways. Astrobiology 12, 775-784 (2012).

62. Burron, I. et al. 3.2 Ga detrital uraninite in the Witwatersrand Basin, South Africa: Evidence of a reducing Archean atmosphere. Geology 46, 295-298 (2018).

63. Donaldson, J. A. \& de Kemp, E. A. Archaean quartz arenites in the Canadian shield: examples from the Superior and Churchill Provinces. Sediment. Geol. 120, 153-176 (1998).

64. Eriksson, K. A., Simpson, E. L. \& Mueller, W. An unusual fluvial to tidal transition in the mesoarchean Moodies Group, South Africa: a response to high tidal range and active tectonics. Sediment. Geol. 190, 13-24 (2006).

65. Heubeck, C. An early ecosystem of Archean tidal microbial mats (Moodies Group, South Africa, ca. 3.2 Ga). Geology 37, 931-934 (2009).

66. Homann, M. et al. Microbial life and biogeochemical cycling on land 3,220 million years ago. Nat. Geosci. 11, 665-671 (2018).

67. Godfrey, L. V. \& Falkowski, P. G. The cycling and redox state of nitrogen in the Archaean ocean. Nat. Geosci. 2, 725-729 (2009).

68. Nabhan, S., Marin-Carbonne, J., Mason, P. R. D. \& Heubeck, C. In situ S-isotope compositions of sulfate and sulfide from the $3.2 \mathrm{Ga}$ Moodies Group, South Africa: A record of oxidative sulfur cycling. Geobiology 18, 426-444 (2020).

69. Hawkesworth, C. J., Cawood, P. A., Dhuime, B. \& Kemp, T. I. S. Earth's continental lithosphere through time. Annu. Rev. Earth Planet. Sci. 45 169-198 (2017).

70. Cardona, T., Sánchez-Baracaldo, P., Rutherford, A. W. \& Larkum, A. W. Early Archean origin of Photosystem II. Geobiology 17, 127-150 (2019).

71. Ward, L. M., Rasmussen, B. \& Fischer, W. W. Primary productivity was limited by electron donors prior to the advent of oxygenic photosynthesis. J. Geophys. Res. Biogeosci. 124, 211-226 (2019).

72. Planavsky, N. J. et al. Evolution of the structure and impact of Earth's biosphere. Nat. Rev. Earth Environ. 2, 123-139 (2021).

73. Burns, J. M. et al. Methods for reactive oxygen species (ROS) detection in aqueous environments. Aquat. Sci. 74, 683-734 (2012). 
74. Kuenen, P. H. Experimental abrasion 3. Fluviatile action on sand. Am. J. Sci. 257, 172-190 (1959).

75. Lewin, J. \& Brewer, P. A. Laboratory simulation of clast abrasion. Earth Surf. Process. Landf. 27, 145-164 (2002).

76. Joo, S. H., Feitz, A. J., Sedlak, D. L. \& Waite, T. D. Quantification of the oxidizing capacity of nanoparticulate zero-valent iron. Environ. Sci. Technol. 39, 1263-1268 (2005).

77. Cohn, C. A., Pak, A., Strongin, D. \& Schoonen, M. A. Quantifying hydrogen peroxide in iron-containing solutions using leuco crystal violet. Geochem. Trans. 6, 47 (2005)

\section{Acknowledgements}

We thank J. William Schopf, Robert E. Blankenship, Noah J. Planavsky, Christopher P. McKay, and anonymous reviewers for their helpful discussions and suggestions. H.H. and J.Z. were supported by National Natural Science Foundation of China (Grant No. 41921003), National Science Fund for Distinguished Young Scholars (41825003), CAS Key Research Program of Frontier Sciences (Grant No. QYZDJ-SSW-DQC023), and the Strategic Priority Research Program (B) of Chinese Academy of Sciences (Grant No. XDB18000000). Y.Li was supported by the Strategic Priority Research Program of Chinese Academy of Sciences (Grant No. XDB41000000). This is contribution No. IS-3096 from GIGCAS.

\section{Author contributions}

H.H. and J.Z. led the projects and designed the experiments; X.W. performed the experiments with assistance from Y.Lv and Y.Y.; H.H., J.Z., X.W., and H.X. analyzed the data; H.H., X.W., Y.Li, and K.K. wrote the manuscript with input from H.X. and J.Z.

\section{Competing interests}

The authors declare no competing interests.

\section{Additional information}

Supplementary information The online version contains supplementary material available at https://doi.org/10.1038/s41467-021-26916-2.

Correspondence and requests for materials should be addressed to Hongping He, Yiliang Li or Kurt O. Konhauser.

Peer review information Nature Communications thanks the anonymous reviewers for their contribution to the peer review of this work. Peer reviewer reports are available.

Reprints and permission information is available at http://www.nature.com/reprints

Publisher's note Springer Nature remains neutral with regard to jurisdictional claims in published maps and institutional affiliations.

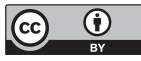

Open Access This article is licensed under a Creative Commons Attribution 4.0 International License, which permits use, sharing, adaptation, distribution and reproduction in any medium or format, as long as you give appropriate credit to the original author(s) and the source, provide a link to the Creative Commons license, and indicate if changes were made. The images or other third party material in this article are included in the article's Creative Commons license, unless indicated otherwise in a credit line to the material. If material is not included in the article's Creative Commons license and your intended use is not permitted by statutory regulation or exceeds the permitted use, you will need to obtain permission directly from the copyright holder. To view a copy of this license, visit http://creativecommons.org/ licenses/by/4.0/.

(C) The Author(s) 2021 